\title{
DAYA HAMBAT EKSTRAK BUAH ANDALIMAN (Zanthoxylum acanthopodium DC) DALAM ETIL ASETAT TERHADAP PERTUMBUHAN Escherichia coli
} Inhibition of Andaliman Fruit Extract (Zanthoxylum acanthopodium DC) in Ethyl Acetate Against The Growth of Escherichia coli.

\author{
Fitri Maria Clarensia Sitanggang1), Agus Selamet Duniajii ${ }^{2)}$, I Desak Putu Kartika Pratiwi ${ }^{2)}$ \\ ${ }^{1}$ Mahasiswa Program Studi Imu dan Teknologi Pangan, Fakultas Teknologi Pertanian, Unud \\ ${ }^{2}$ Dosen Program Studi Imu dan Teknologi Pangan, Fakultas Teknologi Pertanian, Unud \\ PS Ilmu dan Teknologi Pangan, Fakultas Teknologi Pertanian, Universitas Udayana, \\ Kampus Bukit Jimbaran, Badung-Bali
}

\begin{abstract}
This study aims to determine the Minimum Inhibitory Consentration (MIC) of andaliman fruit extract (Zanthoxylum acanthopodium DC) in ethyl acetate against the growth of Escherichia coli bacteria. The design of this study used an experimental method with 10 extract concentrations for MIC testing, namely 10\%, 20\%, 30\%, 40\%, 50\%, $60 \%, 70 \%, 80 \%, 90 \%$ and $100 \%$ with 2 repetitions so that they were obtained 20 experimental units. The variables observed were the formation of clear zones, namely the inhibition produced by the presence of antimicrobial activity from andaliman fruit extract in ethyl acetate against the growth of Escherichia coli. Data from research results are presented in the form of tables, figure and discussed descriptively. Andaliman fruit extracts in ethyl acetate have varying inhibitory forces, namely at the concentrations of concentrations of $10 \%$ to $20 \%$ was $0.65 \mathrm{~mm}$ to $3.15 \mathrm{~mm}$ with weak inhibition categories, concentrations of $30 \%$ to $50 \%$ was $5.25 \mathrm{~mm}$ to $6,60 \mathrm{~mm}$ in the moderate inhibition category and concentrations of $60 \%$ to $100 \%$ showed strong inhibition categories with inhibition diameters of $7.20 \mathrm{~mm}$ to 9.60 $\mathrm{mm}$. Minimum Inhibitory Concentration (MIC) for the growth of Escherichia coli was at the concentration of $60 \%$ with a clear zone diameter of $7.2 \mathrm{~mm}$ with a strong category.
\end{abstract}

Keywords : Andaliman fruit, Escherichia coli, antibacterial.

\section{PENDAHULUAN}

Andaliman merupakan rempah asli dari Sumatera Utara yang disebut sebagai the golden spice from North Sumatera. Tanaman ini ditemukan tumbuh liar di daerah Tapanuli dan dimanfaatkan sebagai rempah pada masakan adat Batak Angkola dan Batak Mandailing. Buah andaliman dipakai sebagai bumbu penyedap masakan yang memberikan rasa pedas dan aroma yang khas (Katzer, 2004). Andaliman telah lama dipergunakan oleh suku batak sebagai campuran masakan untuk berbagai jenis makanan, seperti ikan mas arsik, natinombur, dan saksang. Masakan yang menggunakan buah andaliman umumnya lebih tahan lama (Parhusip et al., 2005). Buah andaliman memiliki kandungan senyawa flavonoid, alkaloid, terpenoid, dan steroid (Nababan, 2012). Senyawa aktif pada suatu bahan umumnya dapat didapatkan dengan cara ekstraksi. Parhusip (2006) mengekstrak buah andaliman menggunakan metode maserasi dengan pelarut etil asetat mampu melarutkan banyak kelompok senyawa seperti alkaloid, flavonoid, terpenoid, saponin, dan steroid. Ekstrak etil asetat juga menghasilkan komponen berbau tajam, komponen itu diduga golongan triterpenoid.

Triterpenoid merupakan golongan terpenoid yang mempunyai aktivitas antioksidan yang sangat bermanfaat bagi kesehatan dan berperan penting untuk mempertahankan mutu produk pangan dari berbagai kerusakan seperti ketengikan, perubahan nilai gizi serta perubahan warna dan aroma makanan. Selain itu senyawa terpenoid pada buah andaliman juga dapat dimanfaatkan sebagai antimikrobia (Wijaya, 1999). Penelitian yang dilakukan oleh 
parhusip et al. (1999), Ardinsyah (2001) dan Yasni (2001) menunjukan bahwa bubuk dan ekstrak buah andaliman bersifat antimikroba terhadap bakteri patogen pangan seperti Bacillus Cereus, Staphylococcus aureus, dan salmonella typhimurium. Pernyataan itu didukung dengan hasil penelitian Adriansyah (2001) yang menggunakan ekstrak etil asetat dengan konsentrasi 5\% mampu menghambat B.cereus sebesar $7.1 \mathrm{~mm}$. Hal ini memberikan peluang bagi buah andaliman sebagai bahan baku senyawa antioksidan dan antimikroba bagi industri pangan dan farmasi (Wijaya, 1999).

Menurut Pelczar and Chan (1986), bakteri Escherichia coli adalah bakteri yang paling banyak digunakan sebagai indikator sanitasi karena bakteri ini adalah bakteri komensal pada usus manusia, umumnya merupakan patogen penyebab penyakit dan relatif tahan hidup di air sehingga dapat dianalisis keberadaannya di dalam air yang sebenarnya bukan medium yang ideal untuk pertumbuhan bakteri. Adanya bakteri patogen ini menunjukan suatu tanda praktek sanitasi yang tidak baik karena bakteri patogen ini dapat berpindah dari tangan ke mulut atau dengan pemindahan pasif lewat makanan, air, susu, dan produk-produk lainnya. Escherichia coli yang terdapat pada makanan dan minuman yang masuk kedalam tubuh manusia dapat menyebabkan gejala seperti diare, mual, muntah, dan penyakit seperti disentri, gastroenteritis, dan berbagai penyakit saluran pencernaan lainnya (Nurwanto, 2007).

Berdasarkan hal tersebut untuk meningkatkan potensi buah andaliman sebagai senyawa antimikroba maka perlu dilakukan penelitian tentang uji Minimum Inhibitory Consentration (MIC) yang dapat menghambat pertumbuhan Escherichia coli secara in vitro.

\section{METODE PENELITIAN}

\section{Tempat dan Waktu}

Penelitian dilaksanakan di Laboratorium Pengolahan Pangan, Laboratorium Analisis Pangan dan Laboratorium Mikrobiologi Pangan, Fakultas Teknologi Pertanian, Universitas Udayana, dari bulan Juli sampai Agustus 2018.

\section{Bahan dan Alat}

Bahan utama yang digunakan adalah buah andaliman kering sebanyak $3 \mathrm{~kg}$ yang diperoleh dari Sidikalang, kabupaten Dairi, Sumatera Utara. Bahan kimia yang digunakan adalah aquades, etil asetat, isolat bakteri Eschericia coli yang diperoleh dari Laboratorium Mikrobiologi Pangan Jurusan Ilmu dan Teknologi Pangan FTP, EMBA (Eosin Methylene Blue Agar) (Oxoid), LB (Lactose Broth) (Merck), NA (Nutrien Agar) (Merck), dan alkohol.

Alat yang digunakan dalam penelitian ini adalah blender, jarum ose, batang bengkok, timbangan analitik, erlenmeyer, (Herma), mikropipet (IKA), freezer, incubator (Memmert), rotary vacuum evaporator (IKA), laminar flow cabinet (Kojair), autoklaf, tip, bunsen, korek api, mikroskop, rak tabung, tabung reaksi (Pyrex), gelas beker (Pyrex), gelas ukur (Pyrex), jangka sorong, hot plate, vortex, cawan petri (Pyrex), botol penyemprot alkohol, pipet tetes, almunium foil, kertas saring, tisu, spirtus, kertas label, dan plastik.

\section{Rancangan Percobaan}

Rancangan penelitian yang digunakan dalam penelitian ini adalah metode eksperimental yang memiliki tujuan untuk mengetahui tingkat penghambatan dan MIC ekstrak buah andaliman dalam etil asetat terhadap pertumbuhan Eschericia coli dengan perlakuan konsentrasi, yaitu :

P1 : $\quad 1 \mathrm{ml}$ ekstrak $+9 \mathrm{ml}$ air steril $=10 \%$

P2 : $\quad 2 \mathrm{ml}$ ekstrak $+8 \mathrm{ml}$ air steril $=20 \%$

P3 : $\quad 3 \mathrm{ml}$ ekstrak $+7 \mathrm{ml}$ air steril $=30 \%$

P4 : $\quad 4 \mathrm{ml}$ ekstrak $+6 \mathrm{ml}$ air steril $=40 \%$

P5 : $\quad 5 \mathrm{ml}$ ekstrak $+5 \mathrm{ml}$ air steril $=50 \%$

P6 : $\quad 6 \mathrm{ml}$ ekstrak $+4 \mathrm{ml}$ air steril $=60 \%$ 
P7 : $\quad 7 \mathrm{ml}$ ekstrak $+3 \mathrm{ml}$ air steril $=70 \%$

P8 : $\quad 8 \mathrm{ml}$ ekstrak $+2 \mathrm{ml}$ air steril $=80 \%$

P9 : $\quad 9 \mathrm{ml}$ ekstrak $+1 \mathrm{ml}$ air steril $=90 \%$

P10 : $10 \mathrm{ml}$ ekstrak $=100 \%$

Masing-masing perlakuan diulang sebanyak 2 kali sehingga diperoleh 20 unit percobaan. Data hasil penelitian disajikan secara deskriptif dengan menampilkan tabel dan gambar.

\section{Pelaksanaan Penelitian}

Pelaksanaan penelitian meliputi beberapa tahapan yaitu pembuatan ekstrak buah andaliman, pengujian konfirmasi Escherichia coli, pengujian MIC ekstrak buah andaliman dalam etil asetat terhadap pertumbuhan Escherichia coli.

\section{Persiapan Sampel}

Persiapan sampel meliputi persiapan bahan-bahan, pengecilan ukuran buah andaliman kering yang diayak menggunakan ayakan 60 mesh sampai berbentuk bubuk dan persiapan ekstraksi.

\section{Ekstraksi Buah Andaliman}

Pembuatan ekstrak buah andaliman dilakukan dengan menggunakan metode maserasi. Sebanyak 100 gram bubuk buah andaliman dimasukkan ke dalam etil asetat sebanyak $1000 \mathrm{ml}$ (1:10) dan didiamkan selama 24 jam dengan beberapa kali diaduk. Ekstrak disaring untuk memisahkan ampas dan filtratnya. Selanjutnya filtrat dievaporasi pada suhu $40^{\circ} \mathrm{C}$ sehingga didapatkan ekstrak kental. Ekstrak kental yang diperoleh ditimbang dan disimpan didalam desikator sebelum digunakan untuk uji selanjutnya (Selawa et al., 2013 yang dimodifikasi).

\section{Persiapan bakteri}

Pada tahap perisapan bakteri Escherichia coli menggunakan metode Juniarhati (2011) dalam Putra (2015). Penyegaran bakteri Escherichia coli ATCC 25922 dimulai dengan menginokulasi 1 ose biakan isolat Escherichia Coli dalam media NA ke dalam tabung reaksi yang berisi $5 \mathrm{ml}$ media LB steril kemudian diinkubasi pada temperature $37^{\circ} \mathrm{C}$ selama 24 jam. Pertumbuhan bakteri Escherichia coli dapat dilihat dengan adanya kekeruhan pada media LB.

\section{Uji Konfirmasi Bakteri Escherichia coli ATCC 25922}

Tahap pertama pada pengujian ini adalah pengamatan bentuk dan warna koloni isolat. Bakteri yang sudah disegarkan kemudian dibiakan pada media EMBA dengan cara digoreskan agar diperoleh koloni tunggal dan diinkubasi selama 24 jam dengan suhu $37^{\circ} \mathrm{C}$. Diamati bentuk dan warna koloni bakteri (Juniarthati, 2011). Escherichia coli mempunyai ciri-ciri yaitu berwarna hijau metalik, bentuk bulat, elevasi mencembung, dan pinggiran bulat utuh.

Tahap kedua adalah pewarnaan Gram dan pengamatan bentuk sel. Pewarnaan gram dilakukan dengan cara isolat bakteri yang telah disegarkan diratakan pada kaca objek yang sudah dibersihkan dan difiksasi $\pm 20 \mathrm{~cm}$ diatas api bunsen. Preparat ditetesi dengan pewarna kristal violet yang didiamkan selama \pm 1 menit, kemudian dibilas dengan air mengalir dengan posisi preparat dimiringkan dan larutan lugol kemudian didiamkan selama 1 menit dan kembali dibilas serta dikeringkan. Preparat kembali ditetesi dengan etanol 95\% dan didiamkan selama \pm 30 detik dan kembali dibilas serta dikeringkan. Terakhir, preparat ditetesi dengan safranin dan didiamkan selama 10-20 detik, kemudian dibilas dan dikeringkan seperti hal sebelumnya, lalu preparat diamati dibawah mikroskop dengan pembesaran 1000 kali (Juniarthati, 2011). Pewarnaan Gram pada Escherichia coli sesuai dengan bakteri Gram negatif, yaitu akan berwarna merah saat diamati dengan mikroskop dan bentuk selnya batang pendek. 


\section{Penentuan Minimum Inhibitory Concentration (MIC)}

Penentuan MIC ini dilakukan dengan 10 konsentrasi ekstrak buah andaliman. Pembuatan konsentrasi ekstrak buah andaliman dalam etil asetat untuk uji MIC terhadap bakteri Escherichia coli yaitu 10\%, 20\%, 30\%, 40\%, $50 \%, 60 \%, 70 \%, 80 \%, 90 \%, 100 \%$. Pengujian MIC dilakukan dengan dua kali ulangan sehingga menghasilkan 20 unit percobaan. Metode penentuan dilakukan dengan cara difusi agar (sumuran). Menurut Setiawan et al. (2017) biakkan bakteri diinokulasikan pada cawan petri dengan media NA kemudian diberi lubang dengan bantuan tabung durham. Ekstrak berbagai konsentrasi dimasukkan dalam sumur pada media NA sebanyak 20 $\mu \mathrm{L}$, setelah itu diinkubasi selama $1 \times 24$ jam pada suhu $37^{\circ} \mathrm{C}$. Kontrol negatif yang digunakan adalah aquades dan kontrol positif menggunakan antibiotik tetrasiklin. Diukur zona bening yang terdapat di sekitar sumur pada masing-masing konsentrasi ekstrak dengan jangka sorong. Konsentrasi minimum yang dapat menghambat pertumbuhan bakteri Escherichia coli merupakan MIC.

\section{Variabel yang diamati}

Variabel yang diamati adalah besarnya diameter zona bening yang dibentuk oleh ekstrak andaliman dalam satuan milimeter (mm) terhadap Escherichia coli pada media NA (Nutrien Agar) dari masing-masing konsentrasi. Zona penghambatan merupakan daerah penghambatan berupa area bening yang mucul di sekeliling lubang sumur. Zona penghambatan diukur dengan jangka sorong sebanyak empat kali di tempat yang berbeda dan hasilnya dirata-ratakan kemudian dikurangi dengan diameter sumur (Amanah, 2011).

\section{HASIL DAN PEMBAHASAN}

\section{Uji Konfirmasi}

Uji konfirmasi terhadap Escherichia coli ATCC 25922 meliputi bentuk dan warna koloni, pewarnaan gram, dan bentuk sel. Hasil uji kofirmasi bakteri Escherichia coli ATCC 25922 dapat dilihat pada Tabel 1.

Table 1. Uji Konfirmasi bakteri Escherichia coli ATCC 25922

\begin{tabular}{lll}
\hline No & Karakteristik & Uji Konfirmasi \\
\hline 1. & Bentuk koloni & Bulat \\
2. & Warna koloni & Hijau metalik \\
3. & Pewarnaan gram & Gram negatif \\
4. & Bentuk sel & Batang Pendek \\
\hline
\end{tabular}

Berdasarkan Tabel 1. dapat dilihat bahwa Escherichia coli ATTC 25922 yang tumbuh pada media EMBA setelah diinkubasi suhu $37^{\circ} \mathrm{C}$ selama 24 jam memiliki ciri-ciri morfologi bentuk koloni bulat, warna koloni hijau metalik, masuk ke dalam Gram negatif, dan bentuk sel batang pendek. Total Escherichia coli yang digunakan pada penelitian ini adalah sebesar $7.5 \times 10^{-13}$ $\mathrm{CFU} / \mathrm{ml}$.

Ciri-ciri morfologi bakteri Escherichia coli yang didapatkan sama dengan yang penelitian Atlas (1993), bahwa bakteri Escherichia coli yg tumbuh pada medium EMBA memiliki warna koloni hijau mengkilat metalik dan bentuk bulat, elevasi mencembung, pinggiran bulat utuh. Hasil pewarnaan Gram memperlihatkan bahwa Escherichia coli mampu menyerap warna merah. Menurut Cappuccino dan Sherman (1987), bakteri yang mampu menyerap warna merah pada pewarnaan Gram termasuk golongan bakteri Gram negatif.

Hasil pengamatan mikrosopik denga pembesaran 1000x menunjukan bahwa Escherichia coli ATCC 25922 merupakan bakteri Gram negatif. Hal ini dibuktikan dengan terbentuknya warna merah pada isolat bakteri Escherichia coli ATCC 25922 di kaca preparat. Pewarnaan Gram ini memiliki kemampuan untuk membedakan dua golongan besar bakteri yaitu bakteri Gram positif dan bakteri Gram negatif. Perubahan warna disebabkan karena bakteri Gram positif 
90\% dari dindingnya terdiri dari lapisan peptidoglikan dan lapisan lainnya adalah asam teikoat sedangkan bakteri Gram negatif hanya memiliki 5-20\% dari dinding selnya terdiri dari lapisan peptidoglikan, sedangkan lapisan lainnya terdiri dari protein, lipopolisakarida, dan lipoprotein. Perbedaan ketebalan lapisan peptidoglikan bakteri Gram positif dan Gram negatif mempengaruhi dari pewarnaan Gram karena bakteri Gram positif saat proses pencucian dengan alkohol setelah penambahan kristal violet dan lugol akan tetap berwarna ungu sedangkan bakteri Gram negatif akan berubah warna menjadi merah karena tidak cukup tebal memiliki peptidoglikan yang keluar dari dinding sel akibat pencucian oleh alkohol. Penambahan safranin akan membuat bakteri Gram negatif menyerap zat warna merah karena bakteri Gram negatif akan menyerap zat warna sehingga mempertegas warna merah pada bakteri Gram negatif, sedangkan bakteri Gram positif tidak berpengaruh pada safranin sehingga warna tetap menjadi ungu (Fardiaz, 1989). Hasil pengamatan dengan mikroskopik dapat dilihat pada Gambar 1.

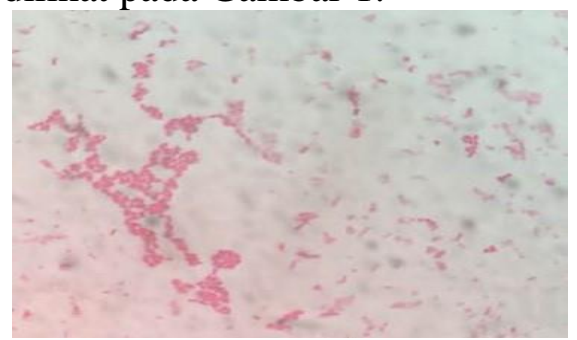

Gambar 1. Pengamatan bakteri dengan mikroskop pada pembesaran 1000x

Hal ini sesuai dengan pernyataan Carter dan Wise (2004), bakteri Escherichia coli berbentuk batang pendek, lurus, tunggal termasuk Gram negatif. Anggraeni (2015) juga menyatakan bahwa hasil yang didapatkan sel bakteri Escherichia coli menunjukkan warna merah dengan koloni berbentuk basil (batang pendek) maupun rantai memanjang.

\section{Minimum Inhibitory Consentration (MIC)}

Berdasarkan hasil analisis nilai MIC ekstrak buah andaliman dalam etil asetat terhadap pertumbuhan Escherichia coli dengan menggunakan metode difusi sumur menunjukan bahwa ekstrak buah andaliman memiliki konsentrasi penghambat minimum terhadap pertumbuhan bakteri Escherichia coli. Konsentrasi MIC terhadap pertumbuhan Escherichia coli dapat dilihat pada Tabel 2.

Table 2. Konsentrasi MIC terhadap pertumbuhan Escherichia coli

\begin{tabular}{ccc}
\hline $\begin{array}{c}\text { Perlakuan } \\
\text { (Konsentrasi) }\end{array}$ & $\begin{array}{c}\text { Diameter } \\
\text { Penghambatan } \\
(\mathbf{m m})\end{array}$ & $\begin{array}{c}\text { Kategori } \\
\text { Penghambatan }\end{array}$ \\
\hline Control (-) & 0 & Lemah \\
Kontrol (+) & 26,51 & kuat \\
$\mathbf{1 0 \%}$ & $0,65 \pm 0,91$ & Lemah \\
$\mathbf{2 0 \%}$ & $3,15 \pm 0,21$ & Lemah \\
$\mathbf{3 0 \%}$ & $5,25 \pm 0,49$ & Sedang \\
$\mathbf{4 0 \%}$ & $6,35 \pm 0,63$ & Sedang \\
$\mathbf{5 0 \%}$ & $6,60 \pm 0,70$ & Sedang \\
$\mathbf{6 0 \%}$ & $7,20 \pm 0,70$ & Kuat \\
$\mathbf{7 0 \%}$ & $7,65 \pm 0,63$ & Kuat \\
$\mathbf{8 0 \%}$ & $8,15 \pm 0,35$ & Kuat \\
$\mathbf{9 0 \%}$ & $8,30 \pm 0,42$ & Kuat \\
$\mathbf{1 0 0 \%}$ & $9,60 \pm 0,56$ & Kuat \\
\hline
\end{tabular}

*Keterangan \pm : Standar deviasi

Pada Tabel 2. Dapat dilihat bawa terdapat variasi penghambatan dari ekstrak buah andaliman dalam etil asetat terhadap pertumbuhan bakteri Escherichia coli. Ekstrak buah andaliman dalam etil asetat dengan konsentrasi 10\%, 20\%, 30\%, 40\%, $50 \%, 60 \%, 70 \%, 80 \%$, 90\%, dan $100 \%$ mempunyai kategori penghambatan lemah, sedang sampai kuat. Hasil penelitian menunjukan bahwa penghambatan ekstrak buah andaliman dalam etil asetat pada konsentrasi $10 \%$ adalah $0,65 \mathrm{~mm}$ dan konsentrasi $20 \%$ adalah $3,15 \mathrm{~mm}$ dengan kategori penghambatan lemah, kemudian pada konsentrasi $30 \%$ adalah $5,25 \mathrm{~mm}$, konsentrasi $40 \%$ adalah $6,35 \mathrm{~mm}$ dan konsentrasi $50 \%$ adalah $6,60 \mathrm{~mm}$ dengan kategori penghambatan sedang dan pada 
konsentrasi $60 \%$ telah menunjukan kategori penghambatan kuat dengan diameter penghambat $7,20 \mathrm{~mm}$, konsentrasi $70 \%$ adalah 7,65 mm, konsentrasi $80 \%$ adalah 8,15 $\mathrm{mm}$, konsentrasi $90 \%$ adalah $8,30 \mathrm{~mm}$ dan hasil tertinggi terdapat pada konsentrasi $100 \%$ dengan diameter penghambatan 9,60 $\mathrm{mm}$. Pada Tabel 3. dapat dilihat nilai MIC terdapat pada konsentrasi $60 \%$ dengan diameter penghambatan sebesar 7,20 $\mathrm{mm}$ dengan kategori penghambatan kuat.

Selain itu, penelitian ini juga menggunakan kontrol positif yaitu antibiotik tetrasiklin yang berguna sebagai pembanding atau tolak ukur dalam menentukan kemampuan ekstrak dalam menghambat bakteri. Berdasarkan hasil penelitian, tetrasiklin dengan konsentrasi $100 \%$ memberikan zona hambat dengan ratarata penghambatan $26,51 \mathrm{~mm}$ dengan kategori kuat. Bakteri Escherichia coli sensitif terhadap tetrasiklin, hal tersebut dilihat dari diameter zona bening yang terbentuk cukup tinggi. Jika dibandingkan dengan antibiotik tetrasiklin, penggunaan ektrak buah andaliman dalam etil asetat pada konsentrasi $100 \%$ memiliki diameter penghambatan 9,60 $\mathrm{mm}$ yang berada dibawah antibiotik tetrasiklin, akan tetapi kategori penghambatan dari ekstrak andalima sudah tergolong kuat. Tetrasiklin merupakan antibiotik yang dapat mengganggu proses sintesis protein dan merupakan antibiotik pilihan yang mampu menghambat bakteri Gram positif maupun Gram negatif, hal ini didasari oleh penelitian Poeloengan (2009) yang menyatakan bahwa antibiotik terasiklin dapat mengambat pertumbuhan bakteri Escherichia coli dengan diameter penghambat $26,0 \mathrm{~mm}$.

Berdasarkan hasil analisis terhadap diameter penghambat, nilai MIC ekstrak buah andaliman dalam etil asetat berada pada konsentrasi $60 \%$ dikarenakan pada konsentrasi terebut merupakan konsentrasi awal dimana diameter penghambatan dari ekstrak buah andaliman dalam etil asetat memiliki nilai penghambatan kuat yaitu sebesar 7,20 mm untuk menghambat pertumbuhan bakteri Escherichia coli. Nilai MIC adalah konsentrasi hambat minimum suatu bahan antimikroba yang dapat menghambat pertumbuhan mikroba. Berdasarkan hal terebut dapat dikatakan pada konsentrasi ekstrak $60 \%$ buah andaliman dapat bersifat sebagai senyawa antibakteri Escherichia coli. Hal tersebut didasari karena senyawa antibakteri yang terkandung dalam bahan akan bersifat stabil dalam menghambat pertumbuhan mikroba bila senyawa antibakteri tersebut memiliki kategori daya hambat kuat. Konsentrasi ekstrak buah andaliman dari $60 \%$ sampai dengan $100 \%$ memiliki diameter zona hambatan pada kisaran 7,20 mm sampai dengan 9,60 mm dengan kategori daya hambat kuat. Suciati et al (2012) menyatakan bahwa suatu bahan dikatakan mempunyai antibakteri apabila diameter hambatan yang terbentuk lebih besar atau sama dengan $6 \mathrm{~mm}$. Variasi penghambatan dari ekstrak buah andaliman dalam etil asetat disebakan oleh konsentrasi ekstrak yang berbeda-beda pula, semakin tinggi konsentrasi ekstrak yang diberikan, maka semakin besar juga daya penghambatannya (Purwoko, 2007). Mekanisme kerja zat antibakteri terjadi dengan merusak dinding sel, mengganggu permeabilitas sel, merusak molekul protein, menghambat aktivitas enzim dan menghambat sintesa nukleat (Jawetz, et. al.,1996; Radji, 2010). Kemampuan ekstrak buah andaliman dalam etil asetat dalam mengambat pertumbuhan bakterinya disebabkan oleh senyawa-senyawa anti bakteri yang terkandung didalamnya. Hasil pengamatan zona bening pada media dapa dilihat pada Gambar 2. 


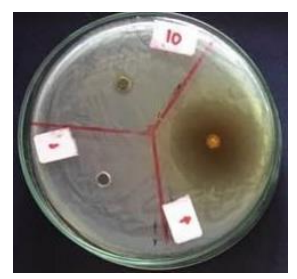

(a)

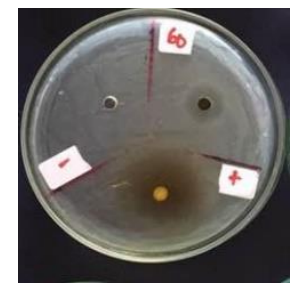

(f)

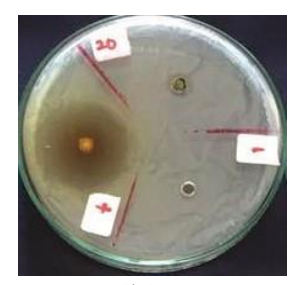

(b)

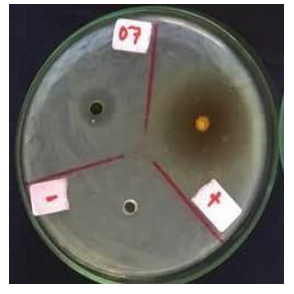

$(\mathrm{g})$

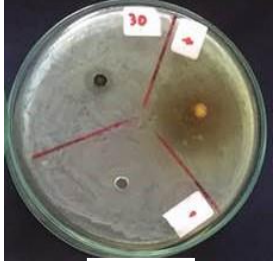

(c)

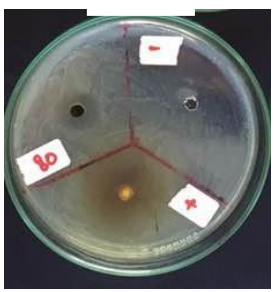

(h)

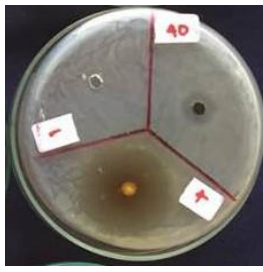

(d)

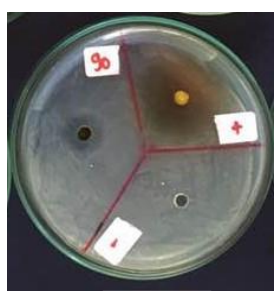

(i)

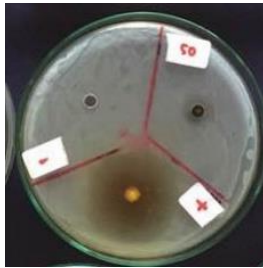

(e)

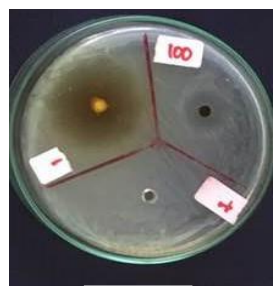

(i)

Keterangan: (a) Konsentrasi 10\% (b) Konsentrasi 20\% (c) Konsentrasi 30\%

(d) Konsentrasi 40\% (e) Konsentrasi 50\% (f) Konsentrasi 60\%

(g) Konsentrasi 70\% (h) Konsentrasi 80\% (i) Konsnetrasi 90\%

(j) Konsnetrasi $100 \%$

Gambar 2. Pembentukan zona bening oleh ekstrak andaliman terhadap pertumbuhan Escherichia coli

Peningkatan konsentrasi ekstrak akan diikuti oleh peningkatan konsentrasi zat bioaktif, sehingga aktivitas antibakteri akan semakin tinggi. Pan et al., (2009) menyebutkan kategori daya hambat pada diameter penghambatan dikelompokan menjadi tiga kategori yaitu pertama termasuk kategori lemah dengan diameter penghambatan $0 \mathrm{~mm}$ $3 \mathrm{~mm}$, kedua termasuk kategori sedang dengan diameter penghambatan adalah $3 \mathrm{~mm}$ - $6 \mathrm{~mm}$ dan ketiga termasuk kategori kuat dengan diameter penghambatan > $6 \mathrm{~mm}$. Konsentrasi senyawa antibakteri berpengaruh terhadap kemampuan menghambat pertumbuhan bakteri. Semakin tinggi konsentrasi zat antibakteri maka semakin tinggi pula kemampuan dalam menghambat pertumbuhan bakteri (Mangunwardoyo et al., 2009). Menurut Davidson dan Naidu (2000) bahwa senyawa terpen dilaporkan merupakan senyawa antimikroba utama rempah andaliman. Selanjutnya Friedman et al., (2004) menyatakan bahwa senyawa terpen tersebut dapat menghambat bakteri Escherichia coli. Selanjutnya Friedman et al., (2004) menyatakan bahwa senyawa terpen tersebut dapat menghambat bakteri Escherichia coli. Senyawa triterpenoid yang termasuk kedalam golongan senyawa terpenoid bersifat antibakteri dengan cara merusak membran sel. Hal ini juga sudah di buktikan oleh penelitian Parhusip (2006) yang menyatakan bahwa ekstrak buah andaliman dengan pelarut etil asetat dapat menghambat pertumbuhan bakteri gram negatif $S$. Typhimurium dengan diameter penghambat sebesar 27,75 $\mathrm{mm}$. Penelitian Lestari et al., (2016) juga melaporkan bahwa ekstrak daun nipah dengan pelarut etil asetat mengandung senyawa triterpenoid dan memiliki aktivitas antibakteri terhadap bakteri Escherichia coli dengan diameter zona hambat yaitu 9,387 $\mathrm{mm}$.

Bagian yang sangat berperan pada ketahanan suatu bakteri adalah struktur dari dinding selnya karena dinding sel berfungsi sebagai pelindung dari lingkungan yang tidak aman. Selain itu membran sel bakteri berfungsi sebagai penyeleksi untuk mengatur keluar masuknya senyawa ke dalam sel 
bakteri. Sehingga terganggunya permeabilitas dari membran sel yang disebabkan oleh senyawa-senyawa metabolit sekunder akan merusak fungsi dari membran sel tersebut, kemudian sel akan mengalami kebocoran. Kebocoran sel ini yang menyebabkan keluarnya komponen sel. Hal ini akan mengakibatkan kerusakan pada sel bakteri tersebut dan bakteri akan menjadi lisis sehingga terjadi kematian sel bakteri. Ada beberapa faktor dan keadaan yang dapat mempengaruhi kerja zat. Siswardi (2002) menjelaskan bahwa faktor-faktor yang mempengaruhi kerja senyawa anti bakteri meliputi konsentrasi zat antibakteri, jenis, umur, keadaan bakteri, suhu, dan waktu inkubasi.

\section{KESIMPULAN DAN SARAN}

\section{Kesimpulan}

Kesimpulan dari penelitian yang telah dilaksanakan yaitu:

1. Ekstrak buah andaliman dalam etil asetat memiliki daya hambat yang bervariasi yaitu pada konsentrasi $10 \%$ sampai $20 \%$ adalah 0,65 mm sampai dengan $3,15 \mathrm{~mm}$ dengan kategori penghambatan lemah, konsentrasi $30 \%$ sampai $50 \%$ adalah 5,25 $\mathrm{mm}$ sampai dengan $6,60 \mathrm{~mm}$ dengan kategori penghambatan sedang dan pada konsentrasi $60 \%$ sampai $100 \%$ menunjukan kategori penghambatan kuat dengan diameter penghambatan 7,20 mm sampai dengan 9,60 $\mathrm{mm}$.

2. Minimum Inhibitory consentration (MIC) terhadap pertumbuhan Escherichia coli adalah pada konsentrasi $60 \%$ dengan diameter zona bening 7,2 $\mathrm{mm}$ dengan kategori penghambatan kuat.

\section{Saran}

Perlu dilakukan penelitian lebih lanjut mengenai daya hambat ekstrak buah andaliman terhadap bakteri lain dan dengan metode yang berbeda.

\section{Daftar Pustaka}

Amanah, N. 2011. Identifikasi dan karakteristik substrat antimikroba dari bakteri asam aktat kandidat probiotik yang diisolasi dari dadih dan yoghurt. Skripsi. Fakultas Peternakan. Institit Pertanian Bogor.

Anggraeni, R. 2015. Analisis Cemaran Bakteri Escherichia coli. 0157:H7 Pada Daging Sapi Di Kota Makassar. [Skripsi]. Kedokteran Hewan, Fakultas Kedokteran, Universitas Hasanuddi Makassar.

Ardiansyah. 2001. Teknik ekstraksi komponen antimkroba buah andaliman (Zanthocylum acanthopodium DC) dan antarasa (Litsea cubeba). [Skripsi]. Bogor: Fakultas Teknologi Pertanian, Institut Pertanian Bogor.

Atlas, R.M., 1993. Handbook of Microbiological Media. CRC. Press Inc., New York.

Cappuccino, J. G. dan N. Sherman. 1987. Microbiology: A Laboratory Manual. The Benjamin/Cummings Publishing Company, Inc. Clifornia.

Carter G. R, D. J. Wise. 2004. Veterinary Bacteriology and Micology. USA: Iowa State Press. Lowa.

Davidson, P. M dan A. S. Naidu. 2000. Antimicrobials in Food: Phyto-phenols. Marcel Dekker.

Fardiaz, S. 1989. Mikrobiologi Pangan. Pusat Antar Universitas. Institut Pertanian Bogor. Bogor.

Friedman, M., P. R Henika, C. E Levin dan R. E Mandreil. 2004a. Antibacterial activities of plant essential oils and their components against Escherichia coli O157:H7 and Salmonella enteritica in apple juice. J Agric Food Chem 52:6042-6048

Jawetz, E., J. L. Melnick, E. A. Adelberg, G. F. Brooks, J. S. Butel, L. N. Ornston, 
1995, Mikrobiologi Kedokteran, ed. 20, University of California, San Fransisco.

Juniarhati, P. E. 2011. Skrining Bakteri Asam Laktat Isolat Susu Sapi Bali Penghasil Bakteriosin Penghambat Bakteri Patogen Escherichia coli Penyebab Diare Akut. Skripsi. Jurusan Farmasi. Unversitas Udayana. Bali.

Katzer, S. 2004. Sichuan Pepper (Zanthoxylum piperatum/simulans/bungeanum/rhetsa/a chanthopodium and others). http://www.ang.kfunigraz.ac.at/katzer/e gl/zant-pip.html. Diakses pada 17 April 2007

Lestari, Y., P. Ardiningsih, dan Nurlina. 2016. Aktivitas Bakteri Gram Positif dan Negatif Dari Ekstrak dan Fraksi Daun Nipah (Nypa fruticans Wurmb) Asal Pesissir Sungai Kakap Kalimantan Barat. Fakultas MIPA. Universitas Tanjung Pura. Pontianak.

Mangunwardoyo, W, Cahyaningsih E, dan Usia T. 2009. Ekstraksi dan Identifikasi Senyawa Antimikroba Herba Meniran (Phyllanthus niruri L.). Ilmu Kefarmasian Indonesia, 7 (2): 57-63.

Nababan, E. N. W. 2012. Histoteknik Hati Mencit (Mus musculus L.) Strain DDW Setelah Pemberian Ekstrak Segar dan Ekstrak Etanol Buah Andaliman (Zanthoxylum acanthopodium DC). Skripsi. Medan: $\quad$ Fakultas

Farmasi. Universitas Sumatera Utara.

Nurwanto. 2007. Tata laksana Higiene Hidangan, Keracunan Hidangan dan Jenis Bakteri.

http://www.ihsmakassar.com. Diakses pada tanggal 17 Juni 2015.

Pan, X., F. Chen, T. Wu, H. Tang, dan Z. Zhao. 2009. The acid, Bile Tolerance and Antimicrobial property of Lactobacillus acidophilus NIT. J. Food Control, 20 : 598- 602 .

Parhusip, A.J.N., P. Sibuea, dan A. Tarigan. 1999. Studi Tentang Aktivitas Antimikroba Alami pada Andaliman. Seminar Nasional Teknologi Pangan. Jakarta, 12-13 oktober 1999.

Parhusip, A.J.N., W.P. Jenie Rahayu, dan S. Yasni. 2005. Pengaruh ekstrak andaliman (Zanthoxylum acanthopodium DC) terhadap permeabilitas dan hidrofobisitas Bacillus cereus. Jurnal Teknologi dan Industri Pangan XVI (1): 24-30.

Parhusip, A.J.N. 2006. Kajian Mekanisme Antibakteri Ekstrak Andaliman (Zanthoxylum acanthopodium DC) Terhadap Bakteri Patogen Pangan. Disertasi. Sekolah Pascasarjana. Bogor. Institut Pertanian Bogor.

Pelezer, M.J. dan E. Chan. 1988. Dasar-Dasar Mikrobiologi. Jilid 2. Penerjemah: Hadioetomo RS, Imas T, Tjitrosomo SS, Angka SL, UI Press. Terjemahan dari Elements of Microbiology. Jakarta.

Poeloengan, M. 2009. Pengaruh Minyak Atsiri Serai (Andropogon citratus DC.) Terhadap Bakteri Yang Diisolasi Dari Sapi Mastitis Subklinis. Balai Besar Penelitian Veteriner. Bogor.

Purwoko, T. 2007. Fisiologi Mikroba. Bumi Aksara, Jakarta

Putra, A.A.N.D.A.W. 2015. Optimasi Waktu Produksi Dan Penghambatan Bakteriosin Dari Bateri Laktat Yang Diisolasi dari Air Susus Ibu (ASI) Terhadap bakteri Escherichia coli ATCC 25922. Skrisi. Fakultas Teknologi Pertanian Universitas Udayana. Denpasar

Radji, M. 2010. Buku Ajar Mikrobiologi Panduan Mahasiswa Farmasi dan Kedokteran. Jakarta: EGC 
Selawa, W., M,R,J. Runtuwee, dan G. Citraningtyas. 2013. Flavonoid dan kapasitas Antiosidan Total Ekstrak etanol daun Binahong (andredrera Cordifulic (Ten.) Steenis.) FMIPA. Universitas Samratulangi. Manado.

Setiawan, E., T. Setyaningtyas, D. Kartika, dan D.R. Ningsih 2017. Potensi Ekstrak Metanol Daun Mangga Bacang $\begin{array}{lll}\text { (Mangiferafoetida } & \text { L.) } & \text { Sebagai }\end{array}$ Antibakteri Terhadap Enterobacteri aerogenes dan Identifikasi Golongan Senyawa Aktifnya. Jurnal Ilmu Kimia Universitas Jendral Soedirman, Vol.2 No.2. Hal: 108-117.

Siswardi, I. 2002. Mempelajari aktivitas antimikroba ekstrak buah andaliman (Zanthoxylum acanthopodium D.C.) terhadap mikroba patogen dan perusak makanan. Skripsi. Fakultas Teknologi Pertanian. IPB, Bogor

Suciati, A, Wardiyanto, Sumino. 2012. Efektifitas ekstrak daun Rhizophora mucronata dalam menghambat pertumbuhan Aeromonas salmonicida dan Vibrio harveyi. e-Jurnal Rekayasa dan Teknologi Budidaya Perairan 1(1): 1-8.

Wijaya, C. 1999. Andaliman, Rempah Tradisional Sumatera Utara dengan Aktivitas Antioksidan dan Antimikroba. Jurnal Hasil Teknologi dan Industri Pangan. Bul Teknol Industri Pangan. Jurusan Teknologi Pangan dan Gizi, Fateta IPB, Bogor 10 (2): 59-61.

Yasni, S. 2001. Aktivitas abtimikroba minyak atsiri buah andaliman (Zanthoxylum acanthopodium DC.) dan antarasa (Litsea cubeba) terhadap bakteri dan kapang serta profil deskriptif komponen aktif penyusun di dalam: nuraida L, Dewanti-Hariyadi R, editor. Pangan tradisional: Basis Bagi Industri Pangan Fungsional dan splemen. Pusat
Kajian makanan Tradisional IPB. Bogor. Hal: 130-138. 
